\title{
Transatlantica
}

Revue d'études américaines. American Studies Journal

\section{Eudora Welty: Sensing the Particular, Revealing the Universal in Her Southern World}

Pearl McHaney

\section{(2) OpenEdition}

1 Journals

\section{Electronic version}

URL: http://journals.openedition.org/transatlantica/5336

DOI: $10.4000 /$ transatlantica.5336

ISSN: $1765-2766$

Publisher

AFEA

\section{Electronic reference}

Pearl McHaney, "Eudora Welty: Sensing the Particular, Revealing the Universal in Her Southern World ", Transatlantica [Online], 1 | 2011, Online since 04 January 2012, connection on 29 April 2021. URL:

http://journals.openedition.org/transatlantica/5336 ; DOl: https://doi.org/10.4000/transatlantica.5336

This text was automatically generated on 29 April 2021.

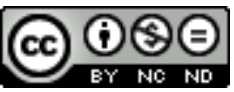

Transatlantica - Revue d'études américaines est mis à disposition selon les termes de la licence Creative Commons Attribution - Pas d'Utilisation Commerciale - Pas de Modification 4.0 International. 


\title{
Eudora Welty: Sensing the Particular, Revealing the Universal in Her Southern World
}

\author{
Pearl McHaney
}

1 In the 1930s, Eudora Welty pursued with equal earnest and talent both fiction and photography and seemed already to be perfecting her visual acuity and its translation into words and image. Of her photograph The Rides, State Fair, for example, Welty cautioned Stuart Wright who was making a portfolio of her photographs, "[T]he Ferris Wheels should be brought out to be right in front of the girls' eyes to dazzle them like an impossible dream." Her statement, regarding a photograph taken more than forty years earlier, reveals Welty's fictional imagination and her metaphorical interpretation, "like an impossible dream," of what the subjects of the photograph feel standing together before the realistic Ferris wheels. "The eye of the camera," Welty says, "record[s] what the eye of the photographer is discovering" (Welty, 2009, 307). The unsayable-human emotions, dreams, relationships-that are Welty's subjects are made visible. "I never doubted," she wrote,

that imagining yourself into other people's lives is exactly what writing fiction is. I had no hesitation [...], only eagerness [...]. I rushed in [...]. I drove my imagination to put me inside [my] characters on a premise I accepted [for my first story and all others] that the emotions in which all of us are alike involved for life, differ more in degree than in kind. Imagining yourself inside the skin, body, heart, and mind of any other person is the primary feat, but also the absolute necessity. (Welty, 2009, 304)

Such imagining of oneself inside another's "body, heart, and mind" involves all of the senses in order to picture the invisible and say the unsayable.

Welty does just this in prose that is poetic, prose that is painted with colors-red, rose, blue, green, silver, black, white, pearly gray, golden-yellow; rich in figurative language, in particular, similes and metaphors; resplendent in sensory images and synaesthesia; and giving of pleasure as it makes the invisible visible. Welty alerts us often to her extraordinary sensitivity for discovering the world for us. In her autobiography one 
Writer's Beginnings, she writes, "The fictional eye sees in, through, and around what is really there" $(1984,85)$ as is illustrated by Welty and her interviewer as they once "stood staring into the silent gloom on the cypress swamp in the Natchez Trace" ("A Visit" 86). The interviewer asked, "'How would you describe that color?" referring to what was "really there"-"the water's strange shade of beige beneath the darker brown of tree shadows. 'Oh, a sort of blue. Like an ink wash,"' Welty answered. "Blue? Ink wash? What was she talking about? And suddenly there it was. [Welty] had seen the color of air" (1996a, 86). Air is often visible in her fiction as well. She describes "the almost-blue shade of mid-morning," a "horizon-curve against blue air," and "the soft blue air of seven o'clock in the evening on the Delta" (2009, 3, 264; 1998a, 137). Such sensitivity to hues and tones of air comes perhaps from Welty's early ambitions to study art and her continuous interest in painting as evidenced in a letter to her friend John Robinson, in which she reports buying colors: "new blue, rose madder, and gamboges yellow" (3 Mar. 1944). In multiple genres, at seemingly every opportunity, Welty gives evidence of seeing color and being sensitive to light.

Welty seems to be quite conscious of her use of sensory powers. Referring to the "one thing [that] is consistent among [...] many Southern writers, [... that is, feeling] passionately about Place," Welty says, it is "[n]ot simply in the historical or philosophical connotation of the word," "but in the sensory, meaning the breathing world of sight and smell and sound, in its earth and water and sky, its time and its seasons" $(2009,245,165)$. Paying close attention to what Welty sees with her "tyrannous eye" (Emerson, 1957, 238) and to how her observations lead to her senses of smell, touch, and sound in the stories "June Recital" and "Moon Lake," letters, commentary on a1930s photograph, and then the stories "A Sketching Trip" and "The Demonstrators," I argue that Welty pictures the invisible and writes the unsayable by her use of the senses with two results. First, she creates a sense of the South that is simultaneously particular and universal. To illustrate this, I analyze passages especially replete in visual and olfactory senses. Second, Welty's sensory language gives meaning to the abstract, universal concepts such as joy, love, art, and fear.

\section{The Senses}

5 In an interview with cultural historian Homi Bhabha, W. J. T. Mitchell, author of Picture Theory (1994), says, "[L]iterary scholars as spectators, connoisseurs, [are] employing all the senses now[...] [T]hey're feeling, seeing, smelling something palpable in the text, while visual-arts students are learning to read" (Bhabha). Elsewhere, Mitchell challenges us to consider the difference between visual literacy, that "seeing is reading," and literary visualcy, that "reading is seeing" $(2008 \mathrm{~b}, 11,13)$. When we see, we are interpreting signs, making meaning, all of which we ascribe to the action of reading, "visual literacy;" we see; therefore, we read and we read all that we see. Mitchell proposes that we readers attend equally to "visualcy," to "seeing," to consider the innate sense of seeing ("visualcy") as possibly primary to the learned action of reading, "literacy." Welty, perhaps most successful writers, does not distinguish between literacy and visualcy, primarily because she is reading and seeing simultaneously without particular attention to either (as we breathe and speak without attention to either action). Mitchell offers a third idea that can guide us in an examination of the sensory in Welty's work when he notes the differences between 
picture and image: that is, a picture can be hung on a wall, an image cannot (2008a, 16). An "image," says Mitchell, "is what appears in the picture, and what survives [the picture's] destruction-in memory, in narrative, and in copies and traces of other media" $(2008 \mathrm{a}, 16)$. Welty reads/sees/experiences the world and oftentimes creates a picture (in her case a painting or a photograph). In writing, Welty accesses the image in the picture, most often through memory and then in the creation of narrative, and in recollecting the senses associated with her literacy, visualcy, and picture making, uses the image in a text, frequently with figurative language that similarly evokes the senses. That Welty accomplishes these multiple, simultaneous feats is evident (without Mitchell's terminology, of course) in her statement that the writer

is always seeing double, two pictures at once in his frame, his and the world's ...; and he works best in a state of constant and subtle and unfooled reference between the two. It is his clear intention-his passion ... to make the reader see only one of the pictures-the author's-under the pleasing illusion that it is the world's; this enormity is the accomplishment of a good story." (1998b, 789)

What a reader typically "reads" in a story is that which Mitchell names the "picture," a picture "that is the world's," according to Welty, at large in the universe, common to any reader; whereas, the author, Welty, "sees" that which Mitchell names the "image."

7 The "image" surviving in memory leads us (and Welty) to consider the non-visual sense of smell that Diane Ackerman, essayist and poet, author of A Natural History of the Senses, calls the "mute sense, the one without words" $(1990,6)$. Ten thousand different odors have been identified, and we absorb odors in our 23,000 breaths a day (Ackerman, 1990, $5,6)$. How are these smells rendered visible in texts? Although the "physiological links between smell and language centers are pitifully weak," writes Ackerman, "[n]ot so the links between the smell and the memory centers, a route that carries us nimbly across time and distance" $(1990,7)$, as Proust has so convincingly shown. Proust's madeleines, bells, and sensory powers in general come readily to mind in a discussion of the senses. Proust's narrator reflects that "when from a long-distant past nothing subsists, after the people are dead, ... the smell and taste of things remain poised a long time, like souls, ready to remind us, waiting and hoping for their moment, [...] in the tiny and almost impalpable drop of their essence, the vast structure of recollection" $(1934,36)$. Ackerman and Edwin T. Morris (Fragrance, Dover, 2002) confirm Proust's narrative thesis: there are "almost no short-term memory with odors" (qtd. in Ackerman, 1990, 11). Smell relies on long-term memory; smell takes us back to childhood. In Swann's Way in volume one of Remembrance of Things Past, Proust's narrator recollects that his aunt's rooms in Combray that he visited in his youth

fascinate our sense of smell, with the countless odours springing from their own special virtues, wisdom, habits, a whole secret system of life, invisible, superabundant and profoundly moral, which their atmosphere holds in solution; smells natural enough indeed, and couloured by circumstances as are those of the neighbouring countryside, but already humanized, domesticated, confined, and exquisite, ... plenishing, domestic smells, ... sweet savour of warm bread, smells lazy and punctual as a village clock, roving smells, pious smells, ... rooms ... saturated with a fine bouquet of a silence ... the smell of soot, ... the fire, baking like a pie the appetizing smells with which the air of the room was thickly clotted, ... [but] I always returned with an unconfessed gluttony to bury myself in the nondescript, resinous, dull, indigestible, and fruity smell of the flowered quilt. $(1934,38)$

8 Proust activates and anthropomorphizes the smells ("roving," "pious") that the narrator remembers. Some smells are "lazy" but still "punctual" like the "village 
clock." This passage not only creates a sense of place that is replete with "the breathing world of sight and smell and sound" that defines place for Welty $(2009,165)$, but it also illustrates with the concluding smell-"nondescript, resinous, dull, indigestible, and fruity"-Proust's means of communicating the invisible, unsayable, abstract sense, understood in memory, of the smell of his aunt's quilt. Only after leading us through myriad, specific, universally-smelled odors is Proust's narrator able to make us "smell" the "nondescript," "indigestible," vaguely "resinous," "dull," and "fruity" quilt. Poet that he is, Proust begins with the concrete before offering the abstract.

As she reported to Jan Nordby Gretlund in an interview, Welty read, savored even, Swann's Way and recollected buying the Modern Library edition in the 1940s at Macy's in New York (Welty, 1996b, 249; Welty, et al., 1984, 11). As in the quoted passage by Proust, Welty's prose is dense in detail, reliant upon sensory evocation. ${ }^{1}$ She writes with similes, metaphors, colors, sounds, touches, tastes, and smells creating the sense of the place in which her characters find themselves and then moves to the invisible and unsayable abstractions that heretofore confounded and silenced her characters. Welty and her characters create complex figures of speech drawing on remembered sensory experiences to attempt communication.

\section{Sensing the South}

Welty's work is replete with visual (using colors especially) and olfactory images that are specific to the South, often with the visual imagery directly intoning the olfactory, giving readers a sensory experience of the South. Black characters in stories from the 1940s and 60s are "sulphur-yellow" and "golden yellow" with "cottonseed meal" from the ubiquitous cotton gins (Stories 467, 746). The room in her first-published story turns "golden-yellow like some sort of flower" when a lamp is lit, "and the walls smelled of it" (Welty 1998b, 154). In "June Recital," Cassie Morrison's mother comes in and out of Cassies's room "leaving the smell of rose geranium behind for the fan to keep bringing at her" (Welty, 1998b, 347). In her reverie, Cassie recalls how Virgie Rainey would come into the room for piano lessons with Miss Eckhart "carrying a magnolia bloom which she had stolen ... carr[ying it] like a hot tureen, and offer[ing] it to Miss Eckhart ... [but] magnolias smelled too sweet and heavy for right after breakfast" (Welty, 1998b, 350, 351). Cassie's olfactory memory carries her from Virgie to Miss Eckhart and then from Miss Eckhart to Mr. Voight who exposes himself to the girls, a memory that makes her bare "her teeth and set them, trying out the frantic look." She scares herself so that "[1]ike a dreamer dreaming with reservations," she shifts back to innocence in the present moment to "chang[e] the color" in her tie-dying of a scarf (Welty, 1998b, 358). When Cassie falls into past memories again and recalls Miss Eckhart and then the drowning of Mr. Sissum whom Miss Eckhart loved, Welty writes, "Cassie would rather remember ... people ... laughing and turning under the blossoming China trees and the heavy crape myrtles that were wound up in honeysuckle. How delicious it all smelled!" (Welty, 1998b, 360).

11 Smell triggers the memory of Cassie's young brother Loch in a similar manner, a literal smell suggesting an odor in the past. Loch disdainfully thinks, "Cassie was carrying on some girls' business that ... smelled terrible to him, as bad as when she painted a hairreceiver with rosebuds and caught it on fire drying it" (Welty, 1998b,339). Welty also extends a literal sense of smell held in an object, and with it a smell of a particular 
place, into a figurative smell of another place: the telescope that Loch looks through smells "of brass and the drawer of the library table" at first, and then, "with the telescope to his eye he even smelled the house [across the yard] strongly" (Welty, 1998b, 335, 336). A third example illustrates Welty yielding to a confluence of olfactory and aural senses: "Enveloping all that the pupils did [in the house next door that Loch "smells"] ... was the smell of cooking. But the smell was wrong, as the pitch of a note could be wrong" (Welty, 1998b, 369). The smell, "wrong, as the pitch of a note could be wrong" is literal, the smell of cabbage that Miss Eckhart, the German piano teacher, cooked in wine-something uncommon in the Southern town's kitchens.

In another story, we read of "four wet black cedars ... [that] smelled bitter as smoke" (Welty, 1998b, 100). Elsewhere, Ran McLain senses that "lilies must have been in bloom somewhere near;" when he takes "a full breath of their ether smell: consciousness could go or not" (Welty, 1998b, 454). The colors and smells of the South-cottonseedmeal-yellow, magnolia, honeysuckle, wet cedars-recalled in the characters' memories suggest the region's stereotypes by which it is known.

In "Moon Lake," the orphan Easter leads the town girls through the swamp. Welty names the flora and paints visual images with metaphors and similes of past experiences, memories, colors, and smells. The effect, haunting and foreboding, is also typically southern.

Their toes exploded the dust that felt like the powder clerks pump into new kid gloves [...]They were eye to eye with the finger-shaped leaves of the castor bean plants, put out like those gypsy hands that part the curtains at the back of rolling wagons, and wrinkled and coated over like the fortune-teller's face. ... At the girls' shoulders Queen Anne's lace and elderberry and blackberry thickets, loaded heavily with flower and fruit and smelling with the melony smell of snake, overhung the ditch to touch them. The ditches had dried green or blue bottoms, cracked and glazed-like a dropped vase. ... Sweet bay and cypress and sweetgum and live oak and swamp maple closing tight made the wall dense .... Closer to the ear than lips could begin words came the swamp sounds-closer to the ear and nearer to the dreaming mind. ... Periods of silence seemed hoarse, or the suffering from hoarseness, otherwise inexplicable, as though the world could stop. (Welty, 1998b, 423-4)

Castor bean and elderberry plants, sweetgum and live oak trees, the dusty paths, the plants' "melony smell of snake," and the "green or blue," "cracked and glazed" ditches of the swamp specifically evoke the South. After such explicitly identifiable images, follow the abstract swamp sounds that are "nearer to the dreaming mind" than words can successfully convey and "periods of silence" that "seemed hoarse" or even more so than hoarse, which is speech that is not fully silent, "suffering from hoarseness." Although this description seems unsatisfactory to the narrator, the "periods of silence" are otherwise "inexplicable." Welty, as does Proust in the passage cited above, begins with specific sensory images and then failing to find an appropriate descriptor, falls into abstractions masked with sensory language.

Welty draws on imagery of Southern flowers described in sensory language in her correspondence as well as in her fiction. To John Robinson, the man she loved who was a pilot in World War II's Mediterranean arena, she wrote of her garden flowers ${ }^{2}$ and the naturalness of a day at the openings and closings of her letters to contain, perhaps, her fears and worries and elsewhere in the letters to explain the difficulties of writing fiction. When trying to explain something abstract-such as her love for Robinson or art or life itself, Welty also relied upon her garden. She wrote, "I dreamed a student 
came to me and said the Leila camellia was the Mozart of camellias," in her dream comparing the flower to the composer, which surely evokes not the master's visage but classical music, perhaps operatic grandeur (3 Mar. 1944). The previous autumn, Welty described "a soft grey day [... with] a delicious smell of mist [....] Today a big beautiful amaryllis opened many flowers-the white kind with pale pink lines, and rose stamens with gold hoods on them, and the most delicious fragrance, like a cool magical something you could drink" (1 Sept. 1943). In this letter, Welty twice describes that which is smelled, the day's air and the amaryllis, with the adjective "delicious," drawing on the sense of taste to conjure a fragrance. In these two examples, the camellia and an amaryllis are specific flowers that would typically be recognized, readily called to the mind's eye. Yet they seem to Welty (in her dream and letter) to require figurative language, a metaphor and a simile. The figures' vehicles, which by I. A. Richard's definition should help the reader to understand some aspect of the tenors (in these instances, the blossoms), are more complex than the flowers themselves. Welty reverses the figures, making the subjects clear, and the image that carries the meaning, not concrete, but fantastic, sensory images: classical music and "a cool magical something you could drink."

\section{Sensing the Abstract}

16 In other letters to Robinson in Europe, written from New York City and then from Jackson, the sense of the South seems insufficient for Welty when she is trying to illustrate true abstractions: "I believe two people always have something infinite between them-with care." How to explain such intimacy that is infinite, intimacy that is not of a particular place and time, but is universal and unending. She distances herself from the man she loves to whom she is writing by positing not themselves but "two people." She tries to elaborate in her next sentence, but it is disjointed; dashes connect the sensory images with no clear syntax: "The color of a day-one sound-a note-as of a French horn-they stay as real as the stars" (n.d. [July 1944]). What she and Robinson share are the "infinite" abstractions: the color of a day, one musical note, stars. Perhaps what she perceives that they share, which she cannot explain concretely, requires some sort of faith. In spring1945, she wrote about great art and about greatness itself:

When you see Perseus [the constellation] tell me how beautiful it is. ... I think that just as great art lives, why could not greatness itself live-its vitality green and fresh as ever, like something growing on-branching of itself into the future. [...] There's nothing finite or absolute in [greatness], that it couldn't live green and flower out in some fine mind away off at any time, through understanding-it seems natural that it should. A sound wave touching a shell on a far shore, or the light coming down from a star, taking centuries-simply the memory of music once... . (19 Mar. 1945)

17 Such a trove of sensory images to explain the subjects of the metaphors: intimacy between two people and great art/greatness itself. The comparisons begin concretelya note from a French horn, a green, flowering plant-but then become as abstract as the subjects-a star, a sound wave touching a beached shell, the memory of music. For such illusive concepts, Welty draws not on her personal sense of the South, but on intimations of the cosmos. 

sensory experiences lead Welty and her protagonist to discoveries about art, innocence, and joy. In the 1930s, Welty took a photograph of an abandoned home [Fig. 1] of some distant relations of Robinson (Marrs, 2002, 81). Called upon to describe the photograph in 1944, Welty drew upon her long-term memory in recollecting a smell on the occasion of seeing the house. She writes, "It was an evening in November or December, with a wind smelling of night-rain filling the air with blowing leaves and the clouds coming over the sky. [The house] seemed haunted and beautiful at the same time-indeed much had happened in it" (Welty, 2009, 72). Welty had sent the photograph to Vogue in March and followed-up with the descriptive text, including the above recollection, in late May (Polk, 1994, 378). The timing is significant because the photograph is a catalyst for her story "A Sketching Trip" written in spring 1944 and sent out for publication two weeks prior to the photograph's description for Vogue (Polk, 1994, 371). The haunted and beautiful house, described in nearly identical terms in the fictional and nonfictional texts, is the site of the story within the story, a remembered childhood tale as told by Miss Mews and now retold by the protagonist Delia as she recalls it when her memory is sensorially triggered. Violence!"-a dramatic auditory substitution of "Violets! Violets!" flowers being hawked from the roadside by children (Welty, 2009, 263). Delia soon contextualizes and controls the memory. Welty's story is of an artist, and Delia notes that the day of the sketching trip is "a day you could touch. It was texture she had always wanted." She wonders if she can now, as an adult, capture the "texture she had felt as a child at Fergusson's Wells-then she had first put out her hand and touched what was around her-an outer world. At the time she knew it-that was the remarkable thing. She knew this was discovery; she had reached with her full reach, put out adoring hands and touched the world" (Welty, 2009, 264). Delia's task for the present day is to recover the past sufficiently to allow her to transform herself back into the wondering, accepting child who sees, smells, touches all and thereby knows the outer world and, holding onto that psychic reality, transfer it back into the present in her painting. She asks herself, "[W]ere you ever able [to show this joy]?-a joy that had no premonition or thinking back, that had neither pity nor calculation or other thought of herself-only touching of the outward pulse, the awareness of a tender surface underneath which flowed and trembled and pressed life itself" (Welty, 2009, 264). As in her letters to Robinson, the syntax is broken with dashes as Welty tries to have her protagonist express an abstract feeling.

A painting of the house, in its romantic, "pristine, untouched state" (Welty, 2009, 273) catches Delia's attention:

[I]t was indeed the haunted house she knew and remembered now. ... She turned her back on the painting and stood lost, thinking of the haunted house as it was the day she saw it-sun-drenched, light-drenched [...] Looking at her memory like a picture of her own, she saw a halfway ruin of a very plain, beautiful, surely rather small Georgian house, the red of a rose. ... The roof over the loggias, fallen to the ground, lay leaning against the house, softened, like a coverlet, wrinkling over the hidden steps, and sea-blue. ... But it had a story. Miss Mews would tell it. ... And what would her story, telling what people did, have come to without the weight of that rose-red brick in the hand, its reach of color into the eyes-the sudden sight, licking like fire at the feet. (Welty, 2009, 274, 276) 
Delia looks "at her memory like a picture of her own" and sees the roof "softened, like a coverlet, wrinkling over the hidden steps, and sea-blue." And "The bricks, baked of the red clay of the place were of a glowing rose," Welty wrote for Vogue readers as she had in her story, "that seemed to hold light on that first dark day we saw it [...] I took some of the fiery bricks home and put them in my garden around a bed of spring bulbs" (Welty, 2009, 72). Welty's visit to the house, the photograph of that house, and the remembered story recalled from Delia's memory, are imagined into "A Sketching Trip"-all held in the sensory imprint of the smell of night rain and the look of the air and the rose-red bricks. Welty's story is created in just the manner of which she wrote to Robinson: "If I feel something and try to say it truly then the easiest way to do it is writing a story" (n.d. [spring 1944]).

"A Sketching Trip" is the tale of the haunting of the rose-brick house by the murdered wife and the doubly fatal duel of her lover and husband the story of which the child Delia hears retold on the afternoon of the evening when Mr. Fergusson shoots his wife's lover Mr. Torrance in the parlor before all the ladies and children, ending for all time the summer respites at Fergusson's Wells. Without the back and forth of memory and present time, without the figurative language rich with sensory images, "A Sketching Trip" deconstructs into the board game Cluedo/Clue: Mr. Fergusson with a rabbit gun in the parlor. In the story, the porch of the guest house on which people had previously "rocked gayly and competitively as chopping sailboats," becomes a porch

full of rockers [...] as all the boxes in the stable stayed full of hens-seemingly busy with bright eyes though they were very still. ... [When Mr. Torrance] went by the porch, clearing his throat, the world changed. The way a night breeze in the moonlight suddenly shatters the intricate pattern of quiet within the leafy porch and someone will rise and another will say, "Well-good night!" and no more stories will be told that night before any child stretched listening on the steps-that was how Mr. Torrance revolted their world. (Welty, 2009, 265, 272).

This is Delia's and our warning that the intricate balances of the world-the night breeze in the moonlight, the innocence of children, the certitude of adults-are about to change.

Welty's final story, a Civil Rights story, “The Demonstrators" (1966) illustrates both the particular and the abstract rendered through the senses. The southern place that Welty accepts as ubiquitous for the regions' writers is made familiar to readers especially through the olfactory and visual senses: the smells of the magnolia, jasmine, honeysuckle, verbena blossoms, the smells of the hot, moist swamps and bayous; the sights of the cotton fields, the black workers, the verdant greens, the blue skies. She also accesses the senses to suggest the difficulty in communicating the abstractions that join or separate humans to or from one another, feelings of bewilderment and of hope, the need to be connected to something in a meaningful way. In "The Demonstrators," Dr. Strickland, a white man, is led to the mill section of town to save the life of a black woman, Ruby (suggesting the red gemstone, later recognized as his family's maid). It is hot, dim, and crowded around Ruby's bed. He removes her "necklace like sharp and pearly teeth," notices that her nipples "cast shadows that looked like figs," and the "sweat in the airless room, in the bed, rose ... like steam from a kettle already boiling" (Welty, 1998b, 735). There is insufficient light, but when a lamp is brought "closer and closer to the girl," it was "like something that would devour her" (Welty, 1998b, 738). To gain some clarity of the situation, his senses heightened but confused, Dr. Strickland compares the unfamiliar with sensory images from his world- 
white teeth, figs, steam from a kettle, but he cannot "read" Ruby's body, and he leaves her bleeding internally.

Outside the crowded house, Dr. Strickland sees that the world under "moonlight everywhere" has changed, and he experiences a moment of vertigo when what seem like ghosts of the women in his life stir from a clothesline pinned, he somewhat shockingly realizes, with their discarded dresses "stretched wide-sleeved across the porch ... like a child's drawing of angels" (Welty, 1998b, 741). On his way home, he realizes that "Patience [with the world at large, with the town, and with his family] had made him tired. He was so increasingly tired, so sick and even bored with bitterness, intractability that divided everybody and everything" (Welty, 1998b, 744). These are Welty's frustrations with the South, its Jim Crow laws, and the murders and disappearances during the Civil Rights struggles. But neither Welty nor her characters can sustain the bitterness that Dr. Strickland names: "[S]uddenly, tonight, things had seemed just the way they used to seem" (Welty, 1998b, 744). He thinks of "some old, trusted, half-forgotten family friend that he had lost sight of since youth. Was it the sensation, now returning, that there was still allowed to everybody on earth a selfsavage, death-defying, private? The pounding of his heart was like the assault of hope, throwing itself against him without stop, merciless" (Welty, 1998b, 744-5). Like Delia's joy, Dr. Strickland's hope is realized through sensory experiences that are recovered in memory. He felt the pounding of his heart and seeking to understand its cause, he conjures the abstraction of hope assaulting him "throwing itself against him without stop, merciless." The past, the friend from his youth and Delia's childhood retreat to Fergusson's Wells, times of innocence, comes to Delia and Dr. Strickland and saves them from their present crises.

As Dr. Strickland drives toward home, he passes Miss Marcia Pope's "dark window" and notes the "thin as matchstick" gallery columns and the "ornamental" decorations that recall "paper fans held up by acrobats" on the bank building where his father's and now his offices are. He recognizes a "black cave of trees," a flagpole that "looked feathery, like the track of a jet that is already gone from the sky," a water tank "pale as a balloon that might be only tethered there" (Welty, 1998b, 745, 746). He sees "a man lying prone and colorless in the arena of moonlight. / The lights of the car fastened on him and his clothes turned golden yellow. The man looked as if he had been sleeping all day in a bed of flowers and rolled in their pollen ..." (Welty, 1998b, 746). Under the night moon, Dr. Strickland's world is destabilized, fragile, but this same moonlight has made a black man colorless, obliterating the signifying blackness that would condemn the man, Dove, of every trouble that has occurred. Although Dove is a black man, his name suggests the white bird of peace, and Welty's prose makes him first colorless and then yellow. Light does not give the air "color" as in earlier examples, but robs the black man of signification, perhaps of significance. "Fastened" by the severe headlights that recall a police car's arresting beams, Dove, no longer black, seems content, a man slumbering in a garden. But no man or woman sleeps among the flowers purposefully. The light has magically turned his overalls golden-yellow, and when Welty breaks the moonlight and the headlight spells, Dr. Strickland makes rational sense of his sensory response (as with the dresses on the clothesline): it is Dove-Ruby's lover? assailant?that is "covered his length in cottonseed meal" (Welty, 1998b, 746). Neither Dr. Strickland nor the cottonseed cover can save Dove, however, for "[b]lood laced his head like a net through which he had broken" (Welty, 1998b, 746). In Welty's story, no street or lunch counter demonstrations take place. Instead, through figurative language plied 
with sensory images, Welty gives a sense of the bitterness, the hope, the secrets, the conflicts that shed blood, realizing both the particulars of the Southern problems and the universal solutions once it can be admitted that one demonstrates even, or especially, by standing by, pretending to be benign.

Welty intuits that to "understand the world," whether it is the world of the South, love, art, or war, whether particular to one place or time or universal and of any or all time, one must "first detect it through the radar net of our senses" (Ackerman, 1990, xv). She states that it must be the job of the writer to present, "steadily visible from its outside, [...] a continuous, shapely, pleasing and furnished surface to the eye. ... Indeed, great fiction shows us not how to conduct our behavior but how to feel" (Welty, 1998b, 784, 810).

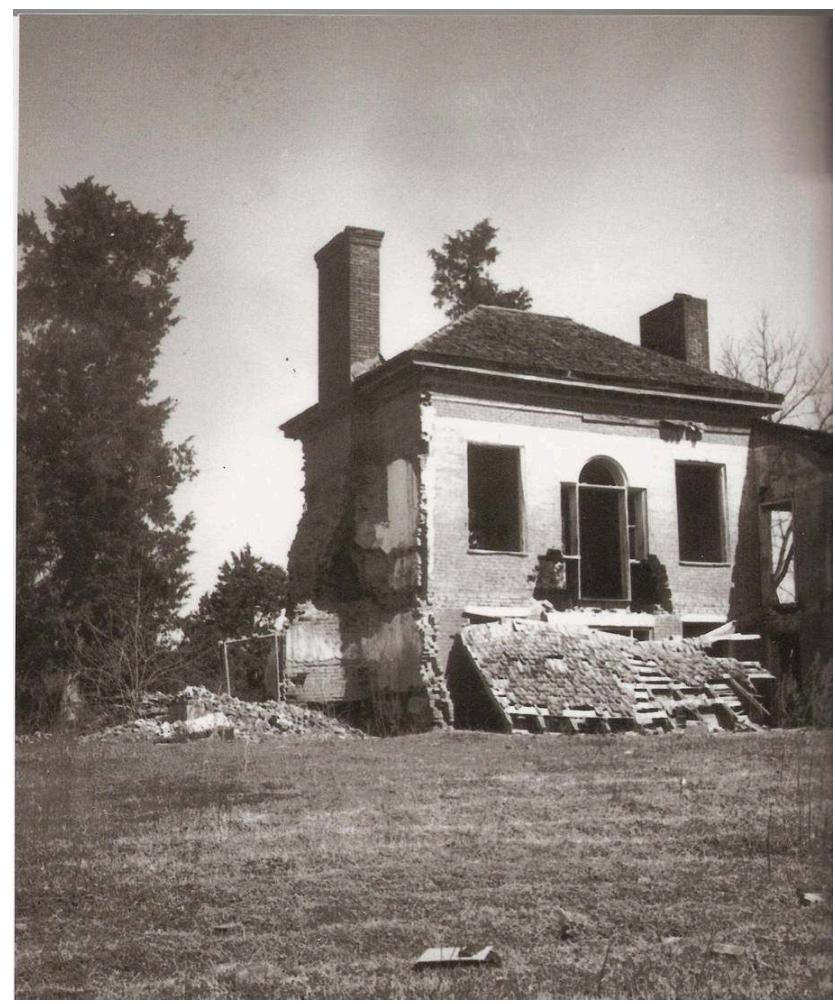

First printed in Vogue, 1 Aug. 1944, 103. In Welty, Photographs, "117. Home abandoned, old Natchez Trace / near Clinton / 1930s". Printed with permission of Eudora Welty, LLC, and the University Press of Mississippi.

\section{BIBLIOGRAPHY}

ACKERMAN, Diane, A Natural History of the Senses, New York, Random House, 1990.

BHABHA, Homi, “Translator Translated,” Interview by W. J. T. Mitchell, http://

prelectur.stanford.edu/lecturers/bhabha/interview.html (last accessed on Sept. $8^{\text {th }}, 2006$.) 
EMERSON, Ralph Waldo, “The Poet," Selections from Ralph Waldo Emerson, Ed. Stephen E.

Wicher, Boston, Houghton Mifflin, 1957, 222-41.

MARRS, Suzanne, One Writer's Imagination, Louisiana UP, 2002.

MITCHELL, W. J. T., "Four Fundamental Concepts of Image Science," Visual Literacy, Ed. James Elkins. New York, Routledge, 2008, 14-29.

---, “Visual Literacy or Literary Visualcy," Visual Literacy, Ed. James Elkins, New York, Routledge, 2008,11-14.

POLK, Noel, Eudora Welty: A Bibliography of Her Work, Jackson, UP Mississippi, 1994.

PROUST, Marcel, Swann's Way, Remembrance of Things Past, vol. 1, Trans. C. K. Scott Moncrieff, New York, Random House, 1934.

WELTY, Eudora, Letters to John Robinson, 1 Sept. 1943, 3 Mar. 1944, n.d. [spring 1944], n.d. [July 1944], 19 Mar. 1945, Eudora Welty Collection. Mississippi Department of Archives and History, Archives and Records Services, Jackson, MS.

---, Letter to Stuart Wright, 12 May 1980, Eudora Welty Collection, Mississippi Department of Archives and History, Archives and Records Services, Jackson, MS.

---, One Writer's Beginnings, Cambridge, Harvard UP, 1984.

---, Photographs, Jackson, UP Mississippi, 1989.

---, “A Visit with Eudora Welty,” Interview by Barbara Lazear Ascher, More Conversations with Eudora Welty, Peggy Whitman Prenshaw, ed., Jackson, UP Mississippi, 1996, 79-86.

---, "Seeing Real Things," Interview by Jan Nordby Gretlund, More Conversations with Eudora Welty, Peggy Whitman Prenshaw, ed., Jackson, UP Mississippi, 1996, 248-61.

---, Complete Novels, New York, Library of America, 1998.

---, Stories, Essays, \& Memoir, New York, Library of America, 1998.

---, Occasions: Selected Writings, Pearl Amelia McHaney, ed., Jackson, UP Mississippi, 2009.

WELTY, Eudora, et al, "The Artist and the Critic," Conversations with Eudora Welty, Peggy Whitman Prenshaw, ed., Jackson, UP Mississippi, 1984, 6-17.

\section{NOTES}

${ }^{1}$ A comparison of stylistics in Proust's Swann's Way with Welty's Delta Wedding (1998a, 90-336) convincingly illustrates Welty's appreciation of Proust and suggests that Proust's prose is at least one of the many influences on Welty's particular use of compounding figures of speech.

${ }^{2}$ Chestina Welty, the author's mother, was a founder of the first garden club in Jackson, Mississippi, and proudly created a continuous-blooming garden that Welty helped to maintain. I am indebted to Julia Eichelberger for her readings of the Welty-Robinson letters, her presentations at the Welty Centennial conference in Jackson, MS, April 2009 and at the American Literature Association conference in Boston, MA, May 2009, and for her generous sharing of her transcriptions of several letters. Letters to Stuart Wright and John Robinson are cited with permission of Eudora Welty, LLC and the Welty Collection at the Mississippi Department of Archives and History. 


\section{ABSTRACTS}

Eudora Welty writes poetic prose that is painted with colors-red, rose, blue, green, silver, black, white, pearly gray, golden-yellow, rich in figurative language, and resplendent in sensory images and synaesthesia. Welty's art illustrates an extraordinary sensitivity for discovering the South, in particular, but also the world at large. Examining how Welty's observations lead to her senses of smell, touch, and sound in the stories "June Recital" and "Moon Lake," selected letters and her comments on one of her photographs, and lastly, the stories "A Sketching Trip" and "The Demonstrators," I argue that Welty pictures the invisible and writes the unsayable by her use of the senses with two results. First, she creates a sense of the South that is simultaneously particular and universal. To illustrate this, I analyze passages especially replete in visual and olfactory senses. Second, Welty's sensory language gives meaning to the abstract, universal concepts such as joy, love, art, and fear.

La prose poétique de Eudora Welty est peinte en couleurs-rouge, rose, bleu, vert, argent, noir, blanc, gris-perle, jaune doré ; riche en langue figurative, et resplendissante d'images sensorielles caractérisées par leur synesthésie. L'art de Welty démontre la sensibilité extraordinaire de l'auteur, sensibilité mise au service de la découverte du monde en général, et du Sud en particulier. A partir de l'étude des observations de Welty et de la manière dont celles-ci sont dominées par les sens de l'odorat, du toucher, et de l'ouïe dans les nouvelles "June Recital" et "Moon Lake," dans une sélection de ses lettres et ses commentaires sur une de ses photographie et dans les histoires "A Sketching Trip" et "The Demonstrators", je démontrerai que Welty dépeint l'invisible et écrit l'imprononçable à travers son emploi des sens, amenant à deux résultats. Tout d'abord, elle créée un paysage sensoriel du Sud qui est à la fois particulier et universel. De manière à illustrer ce phénomène, j'analyse dans mon travail des passages où les références à la vue et à l'odorat sont particulièrement abondantes. Ensuite, le langage sensoriel de Welty lui permet de donner du sens à des concepts universels et abstraits, tels que la joie, l'amour, l'art et la peur.

\section{INDEX}

Keywords: Diane Ackerman, Eudora Welty, Marcel Proust, sensory studies, sight, smell, sound, the South, touch, W.J.T. Mitchell, "June Recital, " photography," “A Sketching Trip, " "Moon Lake," "The Demonstrators

Mots-clés: Diane Ackerman, études sensorielles, Eudora Welty, le sud, Marcel Proust, odorat, ouïe, photographie, toucher, vue, W.J.T. Mitchell, “A Sketching Trip", "June Recital”, "Moon Lake", "The Demonstrators"

\section{AUTHOR}

\section{PEARL MCHANEY}

Associate Professor of EnglishGeorgia State University 